\title{
Service Quality and Financial Performance of Banks (A Meta-Analysis)
}

\author{
Tafa Mosisa Ijara \\ School of management studies, Punjabi University, Patiala, India \\ Email: tafamosisa@yahoo.com \\ DOI: 10.29322/IJSRP.10.05.2020.p10141 \\ http://dx.doi.org/10.29322/IJSRP.10.05.2020.p10141
}

\begin{abstract}
This study reviews previous studies conducted on the relationship between service quality and financial performance in banking industry. Accordingly 40 studies were selected from several journals and websites using convenient selection method. The selected studies were coded, summarized and analyzed using descriptive statistics. The study result shows that service quality directly and indirectly (through mediation of customer satisfaction and customer loyalty) has positive and significant effect on the financial performance of the banks. Service quality has also positive and significant effect on the mediators' customer satisfaction and customer loyalty. This means improvement in service directly drives increase in profitability and also increases customer satisfaction and customer loyalty, then indirectly drives increase in profitability of the banks. Customer satisfaction and customer loyalty positively and significantly affects financial performance of the banks. In general the result depicts positive relationship between service quality, customer satisfaction and financial performance of the banks.
\end{abstract}

Index terms: Banks, financial, performance, Quality and Service

\section{Introduction}

The service profit chain is based on the principle that profitability of a firm is the result of customer satisfaction and loyalty. This means customer satisfaction and loyalty is originates from the customer's sense of value received and which hereafter depends on the productivity, capability, satisfaction and loyalty of employees. According to service profit chain model a customer's sense of value is the result of perceived quality of service and the perceived quality of how that service is delivered relative to the total costs the customer is charged to get those service (Heskett et el., 1997). According to (Duncan and Elliot 2002, Yeung et al., 2002) the significant impact of service quality and the mediating role of customer satisfaction have got good attention from the researcher and service providers. Service quality and customer satisfaction are the well recognized predictors of business performance in the literature.

Corporations and business organization have been given due attention to the service quality because of its direct relationship with customer satisfaction, customer retention, costs, and financial performance (Brown and Swarts, 1989). Customer satisfactions have the direct benefit of retaining loyal customer, which would be less expensive than attracting the new customer (Reichheld and Sasser, 1990). Moreover, full profit potential of each customer can only be achieved by enhancing the profitability of the existing customers, obtaining the new customers and maintaining the relationships (Karimi, Sajedinejad, and Hassannayebi, 2014). Today in global competitive markets, business organizations are trying to hold the customers by meeting their satisfaction and loyalty; so that the ultimate goal of the organizations is to succeed in achieving and retaining the customers repurchase intention and finally financial performance (Egblopeali and Aimin, 2011). Creating satisfaction and loyalty in customers is obtained as the result of superior service quality. The causes for the duration and continuation in function of financial institutions is their ability to provide the services in a desired, secure and proportional form that can lead to the customers' satisfaction and loyalty by meeting their expectations and demands. One of the factors that can guarantee the banks duration is customer-orientation and regard to the customer satisfaction. Enhancement of the customer satisfaction level will cause to enhance the rate of profitability and raises the banks share in the competition market. Customers' satisfaction is not enough and the banks mustn't rely on the customers' satisfaction, they must be promised that their satisfied customers are also loyal. As a result this will increase bank's profitability in the long term. Ultimately service quality in the banks assessment of it through follow is not only the strategy rather having quality of superior service is exactly the distinction aspect between successful and inefficient banks (Khorshidi et el., 2014).

Rapid structural and technological changes, economic uncertainties, more demanding customers, growing competition and market changes significantly change the banking environment all over the world. Therefore, in a highly competitive world the success of any business depends on its human resources and customers (Thakur, 2017).

The empirical evidence indicates banks profitability is highly associated with the quality of services provided by them and satisfaction of customers. The profitability of the banks can be determined by several factors, where service quality is one of the most important 
factors that determine the profitability of the business. Studies have been conducted on the relationship between service quality and profitability of the business. But studies conducted were not significant in number, generated different results and variables are not comprehensively included in these studies. Therefore, Meta analysis is needed to analyze and summarize the results of previous studies. As far as the literature review made is concerned Meta analysis was not conducted on the service quality and financial performance of the banking sector. This study aims to analyze the direct and indirect effect of service quality on financial performance in banking industry.

\section{Literature review and hypothesis 2.1 Service quality and financial performance}

The first service profit chain model was proposed by Heskett et el. (1994), as he hypothesize that revenues are driven by service quality perceptions, which is driven by operational inputs and employee effort. Zahra and Edris (2016) in their study on bank operating in Iran has found that service quality delivered by the studied bank have positive and significant effect on financial performance. With recovery of the service quality the financial performance of bank was increased. The service quality through customer loyalty and satisfaction has indirect, positive and significant effect on financial performance of the bank. (Ahmad, Rehman and Safwan, 2011) however, found that service quality provided by bank has weak impact on the profitability of the banks. Mohmoodi and Asetmal (2014) also found that Electronic service quality has positive impact on profitability. The rise of e-service quality, and customer satisfaction create a positive mindset towards the bank can attract potential customers and earn revenue from these channels effectively and improve financial performance.

Service quality of the bank has positive impact on profitability of the bank. Improvement in service quality results in increase of profitability of the bank (Hari Prasad and Bhavani Prasad 2016, Gyamfi, Acheampong and Asamoah n.d). Study conducted on the impact of adopting electronic banking on banks performance in Nigeria has revealed that the adoption of electronic banking has positively and significantly changed the return on equity of Nigerian banks. But the study also result that electronic banking has not significantly improved the return on assets of the Nigerian banks (Chibueze, Maxwell and Osondu, 2013).

\subsection{Service quality and customer satisfaction}

Zahra and Edris (2016) in their study conducted on banks operating in Iran have found that service quality delivered by the banks have positive and significant effect on customer satisfaction. Electronic service quality has an impact on customer satisfaction (Mohmoodi and Asetmal, 2014). Quality services provided by the bank causes customer satisfaction, which indicates that improving service quality of the bank, increases satisfaction of the customer (Gyamfi, Acheampong and Asamoah n.d). According to study by Sanjuq (2014), quality of services provided by the bank has different effect on satisfaction of the customers. Assurance, which measures customer's feeling of safety, reliability which measures the accuracy and timeliness of the service, and responsiveness which measures how timely a bank reacts to its customers' needs have positive and non significant relationship with customer satisfaction. Tangibility which measures the Company's facilities, equipment and representatives results in positive and significant relationship with customer satisfaction. Adil (2013), Karim and Chowdhury (2014), has also found similar result that all service quality dimensions; tangibles, reliability, assurance, responsiveness, and empathy have positive and significant impact on customer satisfaction.

\subsection{Customer satisfaction and customer loyalty}

Koduah and Farley (2016) study found that there is a significant relationship between customer satisfaction and customer loyalty. According to the result customer satisfaction will lead to customer loyalty in Ghanaian retail banking sector. Customer loyalty is determined also by the joint effect of tangibility, reliability, responsiveness, assurance and empathy. Zahra and Edris (2016) also found on studies conducted on banks operating in Iran that customer satisfaction have positive and significant effect on customer loyalty and financial performance. Increase in customer satisfaction causes to increase the loyalty of studied bank customers.

Customer satisfaction is positively influences customer loyalty and profits of the organization. Regarding this the finding shows that the firms can incur costs of attracting a new customer five times higher than the costs that can be incurred to make the current customer satisfied (Kotler \& Armstrong, 1999). Therefore, they suggest that loyalty has to be developed over a period of time by maintaining the consistent record of meeting (and sometimes exceeding) customer expectation. When the customers reach the level of possessing a positive attitudinal disposition towards the provider, they develop a repeat purchase behavior from a service provider and consider using only one provider when a need for this service exists (Gremler \& Brown, 1996)

\subsection{Customer satisfaction and financial performance}

Service quality through customer satisfaction has positive and significant impact on the financial performance of banks. Improved financial performance is the result of improved banks service that leads customer satisfaction. Satisfied customers repeat their interactions; increase the frequency of their interactions, and by recruiting others into the institution, and to acquaint them with the This publication is licensed under Creative Commons Attribution CC BY. 
institution, that improves the financial performance of the institution (Mohmoodi and Asetmal, 2014). Indirect effect of customer satisfaction is positive and meaningful on financial performance through customer loyalty. Increase in customer satisfaction causes increase in profitability of the bank (Zahra and Edris 2016). (Al-Hawari and Ward 2006), has found similar result that there is positive direct relationship between customer satisfaction and financial performance. The results revealed that customer satisfaction mediating factor through which automated service quality cause impact in bank financial performance.

\subsection{Service quality and customer loyalty}

A study has found that both relational qualities, including satisfaction and trust and mental image and commitment have significant effects on customer loyalty. In the studied private banks customer satisfaction is more critical to customer loyalty. Service quality is found to be an important factor to both customer satisfaction and trust in this study. Improving service quality brings the benefits of increased customer satisfaction and trust. In other words, service quality drives customer satisfaction and trust, then customer satisfaction and trust improves customer loyalty (Nejad, Firoozbakht and Taghipoor, 2014).

The service quality dimensions include assurance, empathy and security reveals as significant predictors of a customer loyalty to Indian Banking sector. The results regarding both, public and private banks implied that mainly enhancement in service quality dimensions assurance and empathy on employees are likely to increase loyalty to a Company, a dimension of customer loyalty. Apart from assurance, empathy the results regarding overall and private sector banks indicate that enhancements in service quality dimension security includes feeling safe in transactions and error free records are likely to increase loyalty to a Company, while the results regarding public sector banks indicate that enhancements in the service quality dimension tangibles includes employees appearance, modern looking equipment in the banks and banks physical facilities are likely to increase loyalty to banking sector(Hazra and Srivastava, 2009). Services quality through mediation of customer satisfaction has positive and meaningful effect on customer loyalty. This means improved service quality increases customer satisfaction and this result causes improved customer loyalty (Zahra and Edris, 2016).

\subsection{Customer loyalty and financial performance}

Customer loyalty has positive and significant effect on the profitability of the bank. Variance in profitability of the bank is explained by the customer loyalty. The research result shows the significant and positive effects of service quality on customer loyalty, and customer loyalty presents remarkably positive effects on corporate performance. Such a result verifies the correlations between customer loyalty and corporate performance. With mediation effect of customer loyalty, customer loyalty to banks performance would be enhanced when the perceived service quality is high that the banks performance would be increased (Chia-Ming, L. and TsungYuan, W. 2017). Services quality through mediation of customer satisfaction has positive and meaningful effect on customer loyalty. This means improved service quality increases customer satisfaction and this result causes improved customer loyalty (Zahra and Edris, 2016).

Customer satisfaction is more critical to loyalty of banks customer. Service quality is found to be an important factor to both customer satisfaction and trust. Improving service quality brings the benefits of increased customer satisfaction and trust. In other words, service quality drives customer satisfaction and trust, then customer satisfaction and trust improves customer loyalty (Nejad, Firoozbakht and Taghipoor, 2014). Zahra and Edris (2016) in their study conducted on banks operating in Iran have found that customer loyalty have positive and significant effect on financial performance. With increase in customer loyalty the financial performance of the bank also increases.

Service quality through customer satisfaction has positive and significant impact on the financial performance of banks. Improved financial performance is the result of improved banks service that leads customer satisfaction. No one is doubt that satisfied customers repeat their interactions which can be considered as the most important source of income for an institution. A satisfied customer can also increase the frequency of their interactions, and by recruiting others into the institution, and to acquaint them with the institution, that improves the financial performance of the institution (Mohmoodi and Asetmal, 2014). Service quality through customer loyalty has positive and significant effect on financial performance, which indicates that improved service quality can lead to increase in the financial performance of the bank through affecting on customer loyalty (Zahra and Edris, 2016). These evidences imply that improved service quality improves customer satisfaction and improved customer satisfaction drives increase in customer loyalty. Finally increase in customer loyalty results increase in financial performance of the bank.

\section{Conceptual framework}

Several studies has found positive relationship between service quality, customer satisfaction, customer loyalty and financial performance of the business organization (Zahra and Edris 2016, Mohmoodi and Asetmal 2014, Chia-Ming, L. and Tsung-Yuan, W. 2017, Nejad, Firoozbakht and Taghipoor 2014, Al-Hawari and Ward 2006). Banking business performance also depends on the quality of service delivered to the customers. Based on these evidences the following framework is developed for this study purpose. Since most of the studies considered service quality as a single variable without analyzing the effect of each service quality elements, this paper also take service quality as one predictor. 


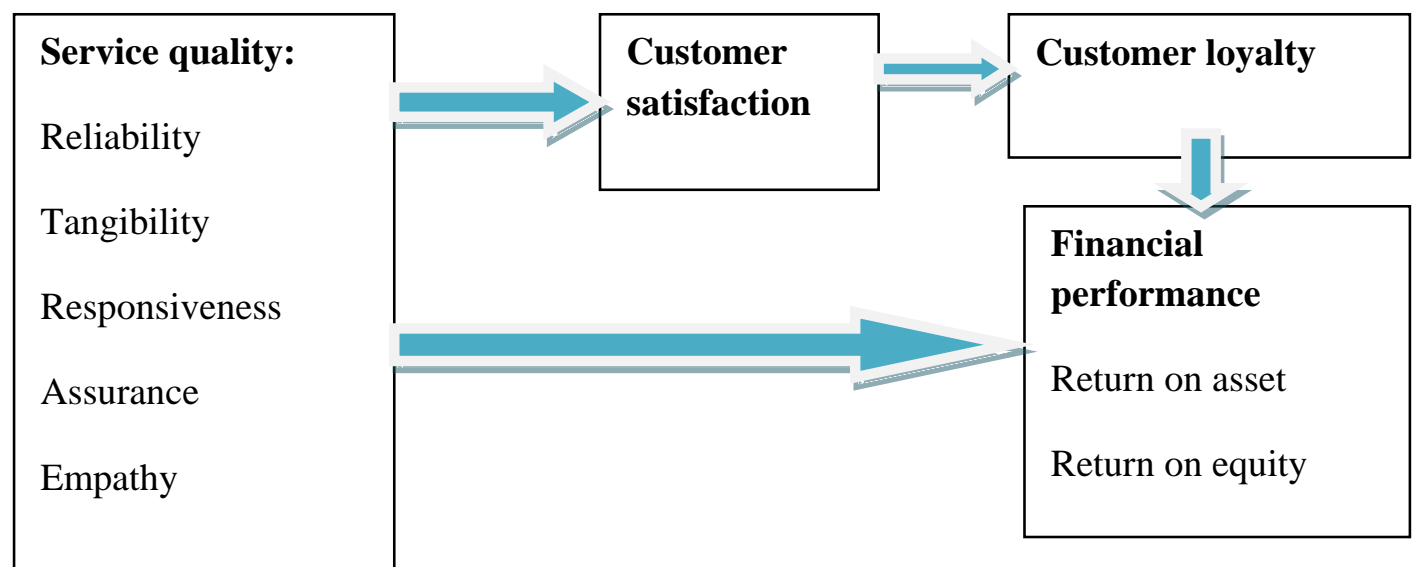

Figure 1: Service profit chain model

Source: adopted from literature

\section{Methodology}

To identify studies for this analysis purpose, I started with determining the type of studies which should be included under the topic. Then studies related to the topic under analysis were intensively searched from all available sources using convenient method. Searches were made from, Elsevier, JSTOR, Emerald and many other journals and websites. The criteria used for the selection of the article in the review are the presence of; a dependent variable measuring financial performance and service related explanatory variables. Financial performance variable measure the profitability of the bank and include; return on assets and return on equity or either of the two. Explanatory variables include service quality (composed of elements tangibility, assurance, reliability, responsiveness and empathy), customer satisfaction and customer loyalty. Only few of the studies reviewed considered the effect of each service quality elements on financial performance and/ or the mediators, while most of the studies used service quality as a single independent variable. Following the empirical evidence this paper also used service quality as one independent variable. Studies not having dependent variable were excluded from the Meta analysis.

All of the 40 studies identified were done on banking industry. Sources of studies used in Meta analysis identifies the author/s, publisher, Publication status, year of publication and country where the study conducted. These information's are depicted in annex 1. .These studies composed of 35 articles and 5 theses. Study sources are shown in annex 1. Meta analysis is a research approach in which the results from many related studies are selected, reviewed and analyzed. After selecting 40 studies which met the set requirements, the studies were checked and coded. Then the results the studies were summarized for the analysis purpose and categorized based on the hypotheses developed from the reviewed literature. Using the relationship between dependent variable and independent variables the analysis was made. The result was analyzed using descriptive statistics that is frequency.

\section{Results and Discussion}

\subsection{Methodology used in reviewed studies}

There are different methodologies used in the studies reviewed. However all studies explain the existence of causal relationship between service quality and financial performance directly and indirectly. Various statistical tools particularly regression analysis and descriptive statistics have provided the most common way to establish the causal relationship between dependent and independent variables. The statistical techniques used in reviewed studies include; 20 studies used regression analysis (Univariate, Bivariate and Multiple regression analysis), 17 studies descriptive statistics (Mean and standard deviation), 6 studies Structural equation modeling and 3 studies used other non parametric methods.

\subsection{Findings}

Studies collected from different sources have used financial performance as dependent variables and service quality as independent variable. Only very small number of studies considered elements of service quality such tangibility, reliability, responsiveness, assurance and empathy as independent variable. On the other hand most of the studies considered service quality as a single independent variable. Therefore, this paper also considers service quality as one independent variable. The reviewed paper considered 
customer satisfaction and customer loyalty as mediator variable and in this paper also considered mediator of service quality and financial performance. Annex 2 depicts the variables used by the reviewed studies and the frequency of variables used by the studies. Studies have found different result on the relationship between dependent variable and independent variables. The level and direction of the effect of the variables on the financial performance is depicted in Annex 3.

\subsection{Discussion and implications}

Studies used for this Meta analysis have made the relationship between service quality and financial performance using different models. All reviewed studies have examined the direct relationship between service quality and financial performance, only some of the studies examined the indirect relationship between service quality and financial performance through mediation of customer satisfaction and customer loyalty. The results of the study are discussed as follows.

Studies found that service quality has positive and significant effect on customer satisfaction, customer loyalty and financial performance of the studied banks. The first analysis is the effect of service quality on financial performance. Out of the total 40 studies used in this Meta analysis 19 studies have found that service quality positively and significantly affects financial performance, 13 studies found that service quality positively affects financial performance but without identifying significance of the effects, 5 studies found that there is no significant relationship between service quality and financial performance and only one study has found that investment in service quality has negative effects on financial performance in short run. So that in sum 32 ( 80 percent) of the 40 studies analyzed have found that service quality positively affects financial performance. Only the remaining 20 percent of the studies found different results. Therefore from these evidences it is possible to conclude that service quality positively affects financial performance of the banking industry.

The second point is the effect of service quality on customer satisfaction. This is used to test the indirect relationship between service quality and financial performance. From studies included in this Meta analysis 10 studies examined the effect of service quality on customer satisfaction. The result of the studies depicts that 7 (70 percent) of the total studies examined the relationship between service quality and customer satisfaction has found that service quality positively and significantly affects customer satisfaction and 3 (30 percent) of the total studies have found that service quality positively affects customer satisfaction but without identifying significance of the effects. Therefore from these results it is possible to conclude that there is positive relationship between service quality and customer satisfaction of the banking industry.

The third result is about the effect of service quality on customer loyalty. Only 6 of the used studies considered customer loyalty as a mediator in the relationship between service quality and financial performance. Out of the 6 studies, only 4 studies have found that service quality has positive and significant effect on customer loyalty. Two studies found that service quality positively affects customer loyalty but without including the significance of the effects. Therefore from the result it is possible to conclude that there is positive relationship between service quality and customer loyalty.

The fourth analysis is the effect of customer satisfaction on customer loyalty. Only 6 of the used studies considered the effect of customer satisfaction on customer loyalty. These 6 studies have found that customer satisfaction has positive and significant effect on customer loyalty. Therefore from the result it is possible to conclude that there is positive relationship between service quality and customer loyalty.

The fifth analysis is the effect of customer satisfaction on financial performance. From studies included in this Meta analysis 13 studies examined the effect of customer satisfaction on financial performance. The result of the studies depicts that 8 (61.5 percent) of the total studies examined the relationship between customer satisfaction and financial performance and has found that customer satisfaction positively and significantly affects financial performance and 4(30.7 percent) of the studies has found that customer satisfaction positively affects financial performance but without identifying significance of the effects. Only one study has found negative effects of the customer satisfaction on financial performance. Therefore from these results it is possible to conclude that there is positive relationship between customer satisfaction and financial performance of the banking industry.

The sixth issue is the effect of customer loyalty on financial performance. From studies included in this Meta analysis 7 studies examined the effect of customer loyalty on financial performance. The result of the studies depicts that 4 (57 percent) of the total studies examined the relationship between customer loyalty and financial performance and has found that customer loyalty positively and significantly affects financial performance and 3(43 percent) of the studies has found that customer satisfaction positively affects financial performance but without identifying significance of the effects. Therefore from these results it is possible to conclude that there is positive relationship between customer loyalty and financial performance of the banking industry.

The seventh issue is the effect of service quality on financial performance through mediation of customer satisfaction and customer loyalty. This means service quality influences customer satisfaction and then satisfied customers improves loyalty and finally increase in customer loyalty increases financial performance. Out of the total studies analyzed 7 seven studies considered the indirect effect of service quality on financial performance through mediation of customer satisfaction and customer loyalty. From the 7 seven studies 6 of them reveals that service quality positively and significantly affects financial performance through mediation of customer satisfaction and customer loyalty and one study shows service quality positively affects financial performance through mediation of customer satisfaction and customer loyalty. In general all studies proves service quality positively affects financial performance through the mediators customer satisfaction and customer loyalty.

In general most of studies that are used in Meta analysis have found the existence of positive relationship between service quality, customer satisfaction, customer loyalty and financial performance. This implies that service quality plays an important role in This publication is licensed under Creative Commons Attribution CC BY. 
retaining the customers and improving the profitability of the firms. So that firms should carefully deliver quality services in order to meet their profit target.

\section{Conclusions}

This study analyzed previous studies conducted by different researchers on the relationships between service quality and financial performance of the banking sector. To conduct the analysis 40 previous studies were selected from journals and thesis using some criteria. Methodologies used and results of these studies are reviewed and discussed. There are different methodologies used in the reviewed studies to test the causal relationship between service quality and financial performance directly and indirectly. Various statistical tools particularly regression analysis and descriptive statistics are the most common method of analysis used in studies.

The results of the study show that service quality has direct positive and significant effect on customer satisfaction, customer loyalty and financial performance of the banks. Customer satisfaction was used as mediator and has positive and significant effect on customer loyalty and financial performance of the banking industry. The other result is customer loyalty has positive and significant effect on the financial performance of the banking industry. Moreover service quality through mediators of customer satisfaction and customer loyalty has positive and significant effect on financial performance of the banks. In general the relationship between service quality, customer satisfaction, customer loyalty and financial performance is positive and significant.

\section{References}

Abusaleem, K.S. and Hersh, A.M. (2016). The Impact of Banking Service Quality on the financial Performance of Saudi Commercial Banks. European Journal of Business and management, 119-126.

Acharya, R.N. Kagan, A. Lingam, S.R. and Gray, K.(2008). Impact of Website Usability on Performance: A Heuristic Evaluation of Community Bank Homepage Implementation. Journal of Business \& Economics Research, 139-148.

Acheampong, I. and Asamoah, K.A.(2013). Service Delivery and Business Growth among Banks in Ghana Using the Service Profit Chain Model. International Journal of Global Business, 57-79.

Adil, M. (2013). The Relationship between Service Quality and Customer Satisfaction in India's Rural Banking Sector, an Item Analysis and Factor-Specific Approach. The Lahore Journal of Business.

Ahmad, A. Ur-Rehman, K. and Safwan, N.(2011). Testing a model of Islamic banking based on service quality, customer satisfaction and bank performance. African Journal of Business Management Vol.5 (5), 1880-1885.

Akhisar, I. Tunay, K.B. and Tunay, N. (2015). The Effects of Innovations on Bank Performance, The Case of Electronic Banking Services. ELSEVIER, 369-375.

Al-Hawari, M. and Ward, T. (2006). The effect of automated service quality on Australian banks' financial performance and the mediating role of customer satisfaction. Emerald insight, 127-147.

Bonface, R. M. and Ambrose, J.(2015). Mobile banking and financial performance of commercial. International Journal of Finance and Current Business Studies, 16-31.

Brown, S. and Swarts, T. (1989). "A gap analysis of professional service quality”. Journal of Marketing, Vol. 53, 92-108.

Liu, C.M., and Wang, T.Y. (2017). A study on the effect of service quality on customer loyalty and corporate performance in financial industry. Problems and Perspectives in Management (open access),15(2-2),355-363. doi:http://10.21511/ppm.15(2-2).2017.05.

Chibueze, A.Z. Maxwell, O.O. and Osondu, N.M.(2013). Electronic Banking and Bank Performance in Nigeria. West African Journal of Industrial \& Academic Research, 171-187.

Cook, L. S., \& Verma, R. (2002). Exploring the linkages between quality system, service quality, and excellence: Service providers [Electronic version]. Quality Management Journal, 9(2), 44-56. Retrieved [insert date], from Cornell University, School of Hospitality Administration site: http://scholarship.sha.cornell.edu/articles/135/

Dinh, V. Le, U. and Le, P.(n.d). Measuring the Impacts of Internet Banking to Bank Performance: Evidence from Vietnam. Journal of Internet Banking and Commerce, 5-11.

Duncan, E. and Elliott, G. (2002), "Customer service quality and financial performance among Australian retail financial institutions". Journal of Financial Services Marketing, Vol. 7 No. 1.

Egblopeali, A.Y. and Aimin,W.(2011). Reoseurly on Effects of Corporate Image, Customer Satisfaction and Switching Cost on Customer Loyalty in Togolese Telecommunication Companies. Proceedings of the 7th International Conference on Innovation \& Management.

Eren S. Selim, Eren M.Sule. Ayas, N. and Hacioglu, G.(2013). The effect of service orientation on financial performance: The mediating role of job satisfaction and customer satisfaction. ELSEVIER Ltd, 665-672.

Garland, B.R. (2001). Service profit chain: A New Zealand retail banking example, a thesis. submitted at Massey University.

Goyit, M.G. and Nmadu, T.M.(2016). Service Quality and Profitability of Banks: A Study of Selected Nigerian Bank, International Journal of Managerial Studies and Research (IJMSR) 29-37.

Gremler, D. D. \& Brown, S. W. (1996). Service loyalty: its nature, importance and implications. Proceedings of American Marketing Association, 171-180.

Gyamfi, A. Acheampong, I and Asamoah, K.A. (n.d). Service delivery and business growth among banks in Ghana using the SPC. Accra Polytechnic, 10-20.

Halili, R.(2014). The impact of Online Banking on Bank Performance. Charles University in Prague, 34-48.

This publication is licensed under Creative Commons Attribution CC BY.

http://dx.doi.org/10.29322/IJSRP.10.05.2020.p10141

WwW.ijsrp.org 
Hazra, S.G. and Srivastava, K.B.L. (2009). Impact of Service Quality on Customer Loyalty, Commitment and Trust in the Indian Banking Sector. Research Gate.

Heskett, J. L., Jones, T. O., Love man, G. W., Sasser, Jr., W. E., Schlesinger, L., (1994). Putting the service-profit chain to work. Harvard Business Review.

Karim, A.R. and Chowdhury, T. (2014). Customer satisfaction on service quality in private commercial Banking sector in Bangladesh. British Journal of Marketing Studies.

Karimi, F., Sajedinejad, A. and Hassannayebi, E.(2014). An Empirical Evaluation of the Service Profit Chain Model in Banking Industry of Iran. Asian Journal of Research in Banking and Finance.

Khorshidi, G.H. Naghash, A. Mohammadian, M. (2014). Assessment and analysis of the services quality gap according to the hierarchy service quality model in keshavarzi bank, journal of economic researches, volume 14, No.1.

Khrawish, H.A. and Al-Sa'di, N.M.(2011). The Impact of E-Banking on Bank Profitability, Evidence from Jordan. Euro Journals Publishing, 142-158.

Koduah, E.Y.T. and Farley, A.Y.D. (2016). Relationship between Customer Satisfaction and Customer Loyalty in the Retail Banking Sector of Ghana. International Journal of Business and Management.

Kombe, S.K. and Wafula, M.K.(2015). Effects of Internet Banking on the Financial Performance of Commercial Banks in Kenya a Case of Kenya Commercial Bank. International Journal of Scientific and Research Publications, 4-9.

Korankye, A.A.(2014). The impact of E-banking on customer service and profitability of banks in Ghana. Global journal of commerce and management perspectives, 61-65.

Kotler, P. \& Armstrong, G. (1999). Principles of Marketing. Upper Saddle River, NJ: Prentice Hall.

Lee, M.C.(n.d). The Causal Relationship between Service Quality, Customer Satisfaction and Profitability in Taiwan Banking Industry. National Chung-Hsing University, 5-10.

Malhotra, P. and Singh, B.(2009). The Impact of Internet Banking on Bank Performance and Risk: The Indian Experience. Eurasian Journal of Business and Economics, 43-62.

Manzoor, M.K and Sumra, S.H.(2011). The Impact of E-Banking on the Profitability of Banks: A Study of Pakistani Banks. Journal of Public Administration and Governance, 31-38.

Mason, E.F.(2015). Quality service and its impact on HFC bank's (Ghana) profitability. International Journal of Economics, Commerce and Management, 1578-1586.

Meihami, B. Varmaghani, Z. and Meihami, H.(2013). The Effect of Using Electronic Banking on Profitability of Bank. Interdisciplinary Journal of Contemporary Research in Business, 1299-1318.

Mohmoodi, A.P. and Asetmal, A.K.(2014). Surveying the Impact Quality of the Bank's electronic Services on Financial Performance (with the Emphasis on the Customer Satisfaction Model). European Journal of Sustainable Development, 97-108.

Mukhongo, H.O.O. Maokomba, C. and Musiega, D. (2014). The effects of alternative banking channels on profitability of commercial banks- case of the Co-operative bank of Kenya. The International Journal of Engineering and Science (IJES), 29-34

Njogu, N.J.(2014). The effect of electronic banking on profitability of commercial banks in Kenya. University of Nairobi, 28-39

Odeny, B.A.(2016). The Influence of Service Quality on Performance of Barclays Bank of Kenya Limited. University of Nairobi, 23 55.

Ogare, H.O.(2013). The effect of electronic Banking on the financial Performance of commercial Banks in Kenya. University of Nairobi, 21-27.

Okiro, K. and Ndungu, J. (2013). The Impact of Mobile and Internet Banking On Performance of Financial Institutions in Kenya. European Scientific Journal, 146-161.

Oyewole, O.S. Abba, M. El-Maude. Gambo, J. Arikpo. and Abam, I.(2013). E-banking and Bank Performance: Evidence from Nigeria. International Journal of Scientific Engineering and Technology, 766-771.

Patel, M.K. Brahmbhatt, M. and Baser, N.(2011). Service quality and bank performance: a comparative Analysis of public and private banks in the state of Gujarat. National Institute of Cooperative Management, 18-24.

Prasad, E.H. and Prasad, G.V.B. (2016). Impact of service quality on performance of banks. VFSTR Journal of STEM, 10-23.

Reichheld, F. F. and Sasser, W. E. (1990). Zero defections: quality comes to services. Harvard business review.

Sanjuq, G. (2014). The Impact of Service Quality Delivery on Customer Satisfaction in the Banking Sector in Riyadh, Saudi Arabia. International Journal of Business Administration.

Siam, A.Z.(2006). Role of the Electronic Banking Services on the Profits of Jordanian Banks. American Journal of Applied Sciences, 1999-2004.

Suratno, S.W.(2015). The Influence of Credit Quality, Service Quality, and Customer Satisfaction on National Banking Performance (A Survey at Indonesia National Banking). Interlink continental journal of Business management and economics, 14-18.

Thakur, M. (2017). Job satisfaction in banking: A study of private and public sector banks. The IUP Journal of Bank Management. Too, V.K. Ayuma, C. and Ambrose, K.(2016). Effects of Mobile Banking on the Financial Performance of Commercial Banks in Kapsabet (Kenya): A Case of Selected Banks in Kapsabet Town. IOSR Journal of Business and Management (IOSR-JBM), 37-48. Uvaneswaran, S.M. Kassa, E.C. and Hamid, S.M.(2017). Challenges in E-Banking services and its impact on profitability of public sector Bank in Ethiopia. International journal of marketing and financial management, 36-46. 
Williams, H.T. Ogege, S. and Ideji, J.O.(2014). An empirical analysis of effective Customers service on Nigeria banks profitability. (a queuing and regression approach). Asian Economic and Financial Review, 864-876.

Yeung, M., Ging, L. and Ennew, C. (2002). "Customer satisfaction and profitability: a reappraisal of the nature of the relationship". Journal of targeting, Measurement and Analysis for Marketing, Vol. 11 No. 1.

Zahra, T. and Edris, M. (2016). Studying the effect of the services quality on financial performance through mediator variables of customer satisfaction and loyalty in banking industry, case study: (Keshavarzi bank branches of Khuzestan province). International journal of humanities and cultural studies, ISSN 2356-5926. pp 119-135.

\section{Annexes}

Annex1: Table 1: Sources for Meta analysis collected from 40 studies

\begin{tabular}{|c|c|c|c|c|c|}
\hline Code & Author/s & Journal (or Publisher) & $\begin{array}{c}\text { Type } \\
\text { (publication } \\
\text { status) }\end{array}$ & Year & Country \\
\hline 1 & Zahra and Edris & $\begin{array}{l}\text { International journal of } \\
\text { humanities and cultural studies }\end{array}$ & Article & 2016 & Iran \\
\hline 2 & Mohmoodi and Asetmal & $\begin{array}{lcc}\text { European } & \text { Journal } & \text { of } \\
\text { Sustainable Development } & \\
\end{array}$ & Article & 2014 & Iran \\
\hline 3 & Al-Hawari and Ward & Emeraldinsight & Article & 2006 & Australia \\
\hline 4 & $\begin{array}{l}\text { Karimi, Sajedinejad, and } \\
\text { Hassannayebi }\end{array}$ & $\begin{array}{l}\text { Asian Journal of Research in } \\
\text { Banking and Finance }\end{array}$ & Article & 2014 & Iran \\
\hline 5 & Khrawish and Al-Sa'di & Euro Journals Publishing & Article & 2016 & Jordan \\
\hline 6 & $\begin{array}{l}\text { Gyamfi, Acheampong } \\
\text { and Asamoah }\end{array}$ & Accra Polytechnic & Article & - & Ghana \\
\hline 7 & $\begin{array}{l}\text { Mukhongo, Maokomba, } \\
\text { and Musiega }\end{array}$ & $\begin{array}{l}\text { The International Journal Of } \\
\text { Engineering And Science }\end{array}$ & Article & 2014 & Kenya \\
\hline 8 & Liu and Wang & $\begin{array}{l}\text { Problems and Perspectives in } \\
\text { Management }\end{array}$ & Article & 2017 & Taiwan \\
\hline 9 & $\begin{array}{l}\text { Akhisar, Tunay and } \\
\text { Tunay }\end{array}$ & ELSEVIER & Article & 2015 & Turkey \\
\hline 10 & Siam, A.Z. & $\begin{array}{l}\text { American Journal of Applied } \\
\text { Sciences }\end{array}$ & Article & 2006 & Jordan \\
\hline 11 & Korankye, A.A & $\begin{array}{l}\text { Global journal of commerce } \\
\text { and management perspectives }\end{array}$ & Article & 2014 & Ghana \\
\hline 12 & $\begin{array}{l}\text { Eren S. Selim, Eren } \\
\text { M.Sule. Ayas, N. and } \\
\text { Hacioglu, G. }\end{array}$ & ELSEVIER & Article & 2013 & Turkey \\
\hline 13 & $\begin{array}{l}\text { Too, Ayuma, and } \\
\text { Ambrose }\end{array}$ & $\begin{array}{l}\text { IOSR Journal of Business and } \\
\text { Management (IOSR-JBM) }\end{array}$ & Article & 2016 & Kenya \\
\hline 14 & Abusaleem and Hersh & $\begin{array}{l}\text { European Journal of Business } \\
\text { and Management }\end{array}$ & Article & 2016 & $\begin{array}{l}\text { Saudi } \\
\text { Arabia }\end{array}$ \\
\hline 15 & $\begin{array}{l}\text { Ahmad, Rehman and } \\
\text { Safwan }\end{array}$ & $\begin{array}{l}\text { African Journal of Business } \\
\text { Management }\end{array}$ & Article & 2010 & Pakistan \\
\hline 16 & $\begin{array}{l}\text { Hari prasad and } \\
\text { Bhavani Prasad }\end{array}$ & VFSTR Journal of STEM & Article & 2016 & India \\
\hline 17 & Goyit and Nmadu & $\begin{array}{lrr}\text { International } & \text { Journal } & \text { of } \\
\text { Managerial } & \text { Studies } & \text { and } \\
\text { Research } & & \\
\end{array}$ & Article & 2016 & Nigeria \\
\hline 18 & Lee & $\begin{array}{ll}\text { National } & \text { Chung-Hsing } \\
\text { University } & \\
\end{array}$ & Article & & Taiwan \\
\hline 19 & $\begin{array}{l}\text { Patel, Brahmbhatt and } \\
\text { Baser }\end{array}$ & $\begin{array}{l}\text { National Institute } \\
\text { Cooperative }\end{array}$ of & Article & 2011 & India \\
\hline 20 & $\begin{array}{l}\text { Acharya, Kagan, } \\
\text { Lingam and Gray }\end{array}$ & $\begin{array}{l}\text { Journal of Business \& } \\
\text { Economics Research }\end{array}$ & Article & 2008 & USA \\
\hline 21 & Odeny & University of Nairobi & Thesis & 2016 & Kenya \\
\hline 22 & Cook and Verma & $\begin{array}{l}\text { Cornell University School of } \\
\text { Hotel Administration }\end{array}$ & Article & 2002 & Hong Kong \\
\hline
\end{tabular}




\begin{tabular}{|c|c|c|c|c|c|}
\hline 23 & $\begin{array}{l}\text { Acheampong and } \\
\text { Asamoah }\end{array}$ & $\begin{array}{l}\text { International Journal of Global } \\
\text { Business }\end{array}$ & Article & 2013 & Ghana \\
\hline 24 & Garland & Massey University & Thesis & 2001 & $\begin{array}{l}\text { New } \\
\text { Zealand }\end{array}$ \\
\hline 25 & Suratno & $\begin{array}{l}\text { Interlink continental journal of } \\
\text { Business management and } \\
\text { economics }\end{array}$ & Article & 2015 & Indonesia \\
\hline 26 & $\begin{array}{l}\text { Uvaneswaran, Kassa and } \\
\text { Hamid }\end{array}$ & 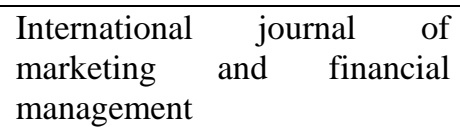 & Article & 2017 & Ethiopia \\
\hline 27 & $\begin{array}{l}\text { Williams, Ogege and } \\
\text { Ideji }\end{array}$ & $\begin{array}{lll}\text { Asian Economic and } & \text { and } \\
\text { Financial Review } & \end{array}$ & Article & 2014 & Nigeria \\
\hline 28 & Njogu & University Of Nairobi & Thesis & 2012 & Kenya \\
\hline 29 & Halili & Charles University In Prague & Thesis & 2014 & Prague \\
\hline 30 & Ogare & University of Nairobi & Thesis & 2001 & Kenya \\
\hline 31 & $\begin{array}{l}\text { Chibueze, Maxwell and } \\
\text { Osondu }\end{array}$ & 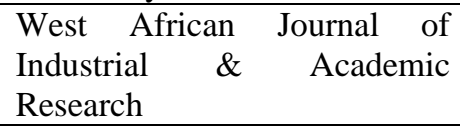 & Article & 2013 & Nigeria \\
\hline 32 & Manzoor and Sumra & $\begin{array}{lr}\text { Journal of } & \text { Public } \\
\text { Administration } & \text { and } \\
\text { Governance } & \\
\end{array}$ & Article & 2011 & Pakistan \\
\hline 33 & Kombe and Wafula & $\begin{array}{lrr}\text { International Journal of } & \text { ou } \\
\text { Scientific and } & \text { Research } \\
\text { Publications } & & \\
\end{array}$ & Article & 2015 & Kenya \\
\hline 34 & $\begin{array}{l}\text { Oyewole, Abba, El- } \\
\text { Maude, Gambo, Arikpo. } \\
\text { and Abam, }\end{array}$ & $\begin{array}{l}\text { International Journal } \\
\text { Scientific Engineering and } \\
\text { Technology }\end{array}$ & Article & 2013 & Nigeria \\
\hline 35 & Malhotra and Singh & $\begin{array}{l}\text { Eurasian Journal of Business } \\
\text { and Economics }\end{array}$ & Article & 2009 & India \\
\hline 36 & Okiro and Ndungu & European Scientific Journal & Article & 2013 & Kenya \\
\hline 37 & $\begin{array}{l}\text { Meihami, Varmaghani } \\
\text { and Meihami }\end{array}$ & $\begin{array}{lrc}\text { Interdisciplinary } & \text { Journal } & \text { Of } \\
\text { Contemporary } & \text { Research } & \text { In } \\
\text { Business } & & \\
\end{array}$ & Article & 2013 & Iran \\
\hline 38 & $\begin{array}{l}\text { Dinh, Uyen Le and } \\
\text { Phuong Le }\end{array}$ & $\begin{array}{l}\text { Journal of Internet Banking } \\
\text { and Commerce }\end{array}$ & Article & & Vietnam \\
\hline 39 & $\begin{array}{l}\text { Bonface, }, \text { R. } \quad \mathrm{M}, \quad \& \\
\text { Ambrose, J. }\end{array}$ & $\begin{array}{l}\text { International Journal of } \\
\text { Finance and Current Business } \\
\text { Studies }\end{array}$ & Article & 2015 & Kenya \\
\hline 40 & Manso & $\begin{array}{lrr}\text { International } & \text { Journal } & \text { of } \\
\text { Economics, Commerce } & \text { and } \\
\text { Management } & & \end{array}$ & Article & 2015 & Ghana \\
\hline
\end{tabular}

Annex 2: Predictor variables of financial performance collected from selected 40 studies

\begin{tabular}{|l|l|l|l|}
\hline \multirow{2}{*}{} & \multicolumn{2}{|c|}{ Variables } \\
\cline { 2 - 4 } & Independent variable & \multicolumn{2}{|c|}{ Mediator variables } \\
\cline { 2 - 4 } & Service quality & Customer satisfaction & Customer loyalty \\
\hline Studies & 40 & 13 & 7 \\
\hline
\end{tabular}

Annex 3: Level and direction of variables effect on financial performance collected from selected 40 studies

\begin{tabular}{|l|l|c|}
\hline & \multicolumn{2}{|c|}{ Effects of Explanatory variables } \\
\cline { 2 - 3 } & Independent variable & Mediator variables \\
\hline
\end{tabular}




\begin{tabular}{|c|c|c|c|}
\hline Code & Service quality & Customer satisfaction & Customer loyalty \\
\hline 1 & $\begin{array}{l}\text { Pos. and sign. effect on cust. Sat., } \\
\text { cust. Loyalty and fin. perf. }\end{array}$ & $\begin{array}{l}\text { Pos. and sig. effect on cust. Loyalty } \\
\text { and fin. Perf. }\end{array}$ & $\begin{array}{l}\text { Pos. and sig. effect on fin. } \\
\text { perf. }\end{array}$ \\
\hline 2 & Pos. and sig. effect on fin.perf. & Pos. and sig. effect on fin. Perf. & \\
\hline 3 & $\begin{array}{l}\text { Pos. and sign. Effect on cust. Sat. } \\
\text { No sig. effect on fin. Perf. }\end{array}$ & $\begin{array}{l}\text { Service quality pos. and sig. affects } \\
\text { perf. And customer satisfaction also } \\
\text { pos and sig affects fin perf. }\end{array}$ & \\
\hline 4 & $\begin{array}{l}\text { Pos. and sig. effect on customer } \\
\text { sat. and cust. Loy }\end{array}$ & $\begin{array}{l}\text { Pos. and sig. effect on cust. Loy. And } \\
\text { profit }\end{array}$ & $\begin{array}{l}\text { Pos. and sig. affects } \\
\text { profitability }\end{array}$ \\
\hline 5 & No sig. effect on profitability & & \\
\hline 6 & Positively affects cust. Satisfy & Pos. affects cust. Loyalty and profit & Pos. affects profitability \\
\hline 7 & Positively affects Profitability & & \\
\hline 8 & $\begin{array}{l}\text { Pos.and sig. effect on cust.loyalty, } \\
\text { profitability }\end{array}$ & & $\begin{array}{l}\text { Pos. and sig. effect on } \\
\text { profitability. } \\
\text { Service quality through } \\
\text { mediating effect of cust. } \\
\text { Loyalty has pos. and sig. } \\
\text { effect on profitability. }\end{array}$ \\
\hline 9 & Positively affects profitability & & \\
\hline 10 & $\begin{array}{l}\text { Investment in service quality } \\
\text { negatively affects in short run }\end{array}$ & & \\
\hline 11 & Positively affects profitability & & \\
\hline 12 & $\begin{array}{llll}\text { Pos. and sig. effect } & \text { on } \\
\text { profitability } & & & \end{array}$ & $\begin{array}{l}\text { Service quality has Pos. and sig. } \\
\text { effect on profitability by mediating } \\
\text { cust. Sat. }\end{array}$ & \\
\hline 13 & $\begin{array}{llll}\begin{array}{l}\text { Pos. and sig. effect } \\
\text { profitability }\end{array} & \text { on } \\
\end{array}$ & & \\
\hline 14 & $\begin{array}{llll}\begin{array}{l}\text { Pos. and sig. effect } \\
\text { profitability }\end{array} & \text { on }\end{array}$ & & \\
\hline 15 & $\begin{array}{l}\text { Pos. and sig. effect on cust. Sat. } \\
\begin{array}{l}\text { insignificant } \\
\text { profitability }\end{array}\end{array}$ & $\begin{array}{l}\text { Negative and insign. Effect on } \\
\text { profitability, so cust. Sat. does not } \\
\text { mediate ser. Quality and profitability. }\end{array}$ & \\
\hline 16 & Positive relationship profitability & & \\
\hline 17 & $\begin{array}{l}\text { There is no significant } \\
\text { relationship between investments } \\
\text { in banks' service quality and the } \\
\text { profitability }\end{array}$ & & \\
\hline 18 & & Pos. and sig. effect on profitability & \\
\hline 19 & $\begin{array}{ll}\begin{array}{l}\text { Positive relationship with } \\
\text { profitability }\end{array} & \\
\end{array}$ & & \\
\hline 20 & $\begin{array}{llll}\begin{array}{l}\text { Pos. and } \\
\text { profitability }\end{array} & \text { sig. effect } & \text { on } \\
\end{array}$ & & \\
\hline 21 & Positively affect profitability & & \\
\hline 22 & $\begin{array}{l}\text { Pos. and sig. effect } \\
\text { profitability }\end{array}$ & & \\
\hline 23 & $\begin{array}{l}\text { Positively affects customer } \\
\text { satisfaction, customer loyalty and } \\
\text { profitability }\end{array}$ & $\begin{array}{l}\text { Positively affects customer loyalty } \\
\text { and profitability }\end{array}$ & $\begin{array}{l}\text { Positively } \\
\text { profitability }\end{array}$ \\
\hline 24 & $\begin{array}{l}\text { Pos. and sig. affects cust. Sat., } \\
\text { cust. Loyalty and profitability }\end{array}$ & $\begin{array}{l}\text { Pos. and sig. affects cust. Loyalty } \\
\text { and profitability }\end{array}$ & $\begin{array}{l}\text { Pos. and sig. affects } \\
\text { profitability }\end{array}$ \\
\hline 25 & $\begin{array}{l}\text { Pos. and sig. affects cust. Sat., } \\
\text { and profitability }\end{array}$ & Pos. and sig. affects profitability & \\
\hline 26 & Positively affects profitability & & \\
\hline
\end{tabular}




\begin{tabular}{|c|c|c|c|}
\hline 27 & Positively affects profitability & & \\
\hline 28 & Pos. and sig. affects profitability & & \\
\hline 29 & $\begin{array}{l}\text { Not significantly affects } \\
\text { profitability }\end{array}$ & & \\
\hline 30 & Pos. and sig. affects profitability & & \\
\hline 31 & Pos. and sig. affects profitability & & \\
\hline 32 & Pos. and sig. affects profitability & & \\
\hline 33 & $\begin{array}{l}\text { Positively affects cust. sat., cust. } \\
\text { Loyalty and profitability }\end{array}$ & & \\
\hline 34 & $\begin{array}{lll}\begin{array}{l}\text { No significant } \\
\text { profitability }\end{array} & \text { effect } & \text { on } \\
\end{array}$ & & \\
\hline 35 & $\begin{array}{l}\text { No significant effect } \\
\text { profitability }\end{array}$ & & \\
\hline 36 & Positively affect profitability & & \\
\hline 37 & $\begin{array}{l}\text { Positively and } \\
\text { affects profitability }\end{array}$ & & \\
\hline 38 & No significant effect on profit & & \\
\hline 39 & Positive impact on profitability & & \\
\hline 40 & $\begin{array}{l}\text { Pos. and sig. effect on } \\
\text { profitability, Positively affects } \\
\text { customer satisfaction }\end{array}$ & $\begin{array}{l}\text { Service quality positively affects } \\
\text { profitability and cust. loyalty by } \\
\text { mediating cust. Satisfaction }\end{array}$ & $\begin{array}{l}\text { Service quality positively } \\
\text { affects profitability by } \\
\text { mediating cust. Loyalty }\end{array}$ \\
\hline
\end{tabular}

* Pos. and sig. = positive and significant

* Cust. Sat. = customer satisfaction

* Cust. Loyalty = customer loyalty

Author: Tafa Mosisa Ijara, PhD candidate in management, school of management studies, Punjabi University, Patiala, India. tafamosisa@yahoo.com 